\title{
Review of Project Planning Methods for Deconstruction Projects of Buildings
}

Felix Hübner • Rebekka Volk• Anna Kühlen • Frank Schultmann

Karlsruhe Institute of Technology (KIT), Institute for Industrial Production (IIP)

Hertzstraße 16, D-76187 Karlsruhe, Germany

felix.huebner@kit.edu

rebekka.volk@kit.edu

anna.kuehlen@kit.edu

frank.schultmann@kit.edu

Keywords: Planning; Planning Methods; Deconstruction; Deconstruction Planning; Deconstruction Planning Methods; Building Deconstruction Planning; Deconstruction scheduling 


\section{Abstract}

\section{Purpose}

The paper aims to provide a comprehensive overview of literature and methods that can be used for deconstruction project planning of buildings. Furthermore, shortcomings of the identified planning methods are presented and research gaps are identified.

\section{Design/methodology/approach}

Requirements to consider for the planning of deconstruction projects are defined, to help in the classification of planning methods. With the help of these requirements, in a detailed literature review strategic and operational planning methods for deconstruction projects are investigated and discussed. Requirements which are not met by any of the identified planning methods can be interpreted as research and/or documentation gaps.

\section{Findings}

On the one hand, the literature review shows that recent approaches deal with planning methods for deterministic time and resource scheduling. Furthermore, project costs can be well planned by several methods. On the other hand, the literature review reveals that recent approaches mostly do not consider risks and uncertainties, environmental hazards or specific safety issues. A major shortcoming is that applied planning methods can only calculate up to a specific level of detail, e.g. with a limited number of activities, due to a very high computational effort in solving such project planning problems exactly.

\section{Originality/value}

To the authors' knowledge, this is the first study that provides an overview of literature and methods for the deconstruction project planning of buildings and it is also the first study that unveils research gaps for future research. Furthermore, the classified planning methods assist in identifying suitable methods for the planning of future deconstruction projects. 


\section{Introduction}

The lifecycle of buildings broadly covers the stages of construction, utilisation and deconstruction/demolition. Deconstruction or demolition occurs at the end of a building's lifecycle. In this paper, the term "building" contains all residential and non-residential buildings (including facilities, such as production or nuclear facilities). The deconstruction of infrastructure is not investigated in this paper. In the following, we will focus on the deconstruction of buildings, which is also described as selective deconstruction or selective dismantling. Schultmann (1998) explains that the advantage of selective deconstruction is that many components or most material of the building can be re-used or recycled. In contrast to that, the re-use- or recycling-rate is much less when a building is demolished (Akbarnezhad et al., 2014; Kühlen et al., 2014; Schultmann, 1998). In this paper, the demolition of a building represents a special type of deconstruction.

Deconstruction, especially selective deconstruction, is at least as complex and sophisticated as the construction process, especially because of many undocumented conditions of the building, which lead to many uncertainties during deconstruction. During their utilisation phase, buildings undergo several modifications, e.g. because equipment and products are installed, removed or adapted or environmental or legal requirements have to be met. Altogether, the conditions, as well as the state of repair and contamination of buildings, are often not documented.

Before its execution, every deconstruction activity must be planned, in order to meet the project objective, which is for example project's makespan or cost minimisation. Because of the uniqueness of every deconstruction project, the planning needs to consider specific characteristics of the related deconstruction processes in buildings, e.g. different use types of buildings (e.g. residential, commercial, industrial, municipal, or infrastructure), which might induce different project objectives, or different age (e.g. new, existing, or heritage), which might result in different building materials and hazardous material contaminations. Furthermore, legal regulations regarding occupational health and safety, including impact limits, protection measures etc. have to be considered. These specialities lead to differ- 
ing requirements and applicability of project planning methods and also strongly influence project outcomes.

For the planning of deconstruction projects, several methods can be applied. To get an idea of which planning methods are appropriate for a specific deconstruction project, an overview of methods for different demands in deconstruction planning would be helpful. Schultmann (1998) investigated existing methods for the deconstruction planning of buildings, but only considered six approaches of operational planning. A short, but not extensive review of strategic and operational project planning methods for deconstruction projects is provided by Xanthopoulos et al. (2012) and Kühlen et al. (2014). These research groups only provided a short description of some papers' content, but did not analyse them in detail concerning several strategic and operational properties. They did not provide a classified, extensive and comprehensive overview of methods that are applied and can be used for deconstruction project planning of buildings. Furthermore, they did not provide an overview of research gaps for this application case.

Bartels (2009) only described planning methods in general, but did not focus on planning methods for deconstruction projects in his literature review. The focus on methods for special demands of project planning in general can also be found in many other contributions, e.g. Schwindt and Zimmermann (2015) or Herroelen and Leus (2004, 2005). Consequently, the existing literature overviews focus on project planning in general or are limited to a small number of existing methods and approaches for the deconstruction planning of buildings. Furthermore, a detailed comparison of the existing methods and approaches is missing. Altogether, to the authors' knowledge, no extensive and comprehensive overview of methods that are applied and can be used for deconstruction project planning of buildings is available. Consequently, this study provides an overview of methods in literature and operational use to close this gap. Furthermore, existing planning methods are classified and research gaps in terms of 'missing methods' are identified. These outcomes are on the one hand relevant and interesting for industry professionals and project managers in the deconstruction sector (e.g. to find an appropriate planning method) and on the other hand for researchers in this area, e.g. to find a research gap for their research. 
The remainder of the paper is structured as follows: Section 2 presents a list of important requirements to consider for deconstruction project planning methods. Section 3 contains the main part of this study and gives a comprehensive literature review on deconstruction project planning methods. Identified planning methods and research gaps are provided and discussed. Section 4 gives a critical appraisal and concludes the review. 


\section{Requirements of planning methods for deconstruction projects}

To achieve project objectives, one must guide the project successfully through the project life cycle, a task known as project management (PM). Suggestions for successful PM and experiences from successfully managed projects are collected in so-called project management standards (PM standards), which are designed to help realize future projects successfully (Bredillet, 2003; Garel, 2013; Ó Conchúir, 2012).

ISO 21500 is an international de jure standard, which is a common guide for project management worldwide. It is very similar to often used de facto standards such as PMBOK-Guide (Project Management Body of Knowledge) (ISO 21500:2012; PMI, 2013). ISO 21500 is divided into the five process groups "Initiating", "Planning”, Implementing", "Controlling” and "Closing”. Furthermore, ten subject groups are relevant to guide a project successfully through the project life cycle. In the following we will focus on the contents of subject groups that are important for the process group "planning" (first column of Table 1).

The subject group "Integration" merges all subject groups, but does not provide necessary information for planning methods. Consequently, we will not focus on integration, but consider it in every single requirement in the following. "Scope" and "time" will be considered with the term "Time" in this study. Concerning ISO 21500, the scope management “[...] includes the processes required to identify and define the work and deliverables [...]" (ISO 21500). Consequently, scope management is the basis for time management on a strategic level (strategic planning). The subject groups "Resource", "Cost", "Risk" and "Quality" will also be considered. Since "Procurement" "[...] includes the processes required to plan and acquire products, services or results, and to manage supplier relationships" (ISO 21500), it relates to "Time" and thus is part of "Time" management in this study. "Communication" is important to spread information and responsibilities, but is not relevant for planning methods. Altogether, in this study we will focus on "Time", "Cost", "Resources", "Risk" and "Quality" to compare planning methods for deconstruction projects. 
In general, project planning is divided into strategic and operational (sometimes also tactical) planning (Steven, 2008; Zimmermann, 2001). Strategic planning is more aggregated than operational planning. For example, strategic planning is about the minimisation of total project duration, whereas operational planning is about the minimisation of single activity duration to meet the strategic goal of project minimisation. Another example is about resources which are necessary for project execution: strategic decisions include for instance, whether to use a specific technique at all. On operational level, decisions regarding resource assignment, staff attendance and resource availability information or their schedule and the logistics onsite are addressed. Altogether, strategic decisions differ from operational planning, but they can have great implications on operational objectives and decisions. Hence, subjects of strategic decisions can be assumed fix on operational level. Moreover, the strategic objectives can be further specified on operational level. Therefore, alternatives in strategic decision making can be modelled as several single activities on operational level. For example, the objective to minimise the overall project duration is further specified by several objectives on operational level and, among others, leads to minimise activity durations, time lags and to parallelise activities. Consequently, strategic and operational planning can differ from each other, but both must be considered in project planning to meet overall project goals (Steven, 2008; Zimmermann, 2001).

Based on the explanations above, in Table 1 the requirements to consider for planning methods are listed. Strategic requirements are given in detail in the second column and a short summary of strategic planning methods is described in section 3.1. In the third column requirements for operational planning are listed. Operational planning methods are described in section 3.2. 
Table 1: Requirements to consider for deconstruction planning methods

\begin{tabular}{|c|c|c|}
\hline $\begin{array}{c}\text { Fields of } \\
\text { consideration }\end{array}$ & $\begin{array}{l}\text { Requirements to consider for strategic } \\
\text { deconstruction planning }\end{array}$ & $\begin{array}{l}\text { Requirements to consider for operational } \\
\text { deconstruction planning }\end{array}$ \\
\hline time & - overall project duration & $\begin{array}{l}\text { - } \text { activity durations, } \\
\text { - time restrictions (e.g. deadlines, idle } \\
\text { times, setup time, due dates, release } \\
\text { dates), } \\
\text { - precedence, } \\
\text { - time lags }\end{array}$ \\
\hline cost & $\begin{array}{l}\text { - overall project costs in general } \\
\text { - overall direct costs of activities of } \\
\text { deconstruction and material han- } \\
\text { dling } \\
\text { - indirect costs of the site in terms of } \\
\text { site facilities }\end{array}$ & $\begin{array}{ll}\text { - } & \text { activity cost } \\
\text { - } & \text { indirect cost } \\
\text { - } & \text { direct disposal cost/ recycling revenues }\end{array}$ \\
\hline resources & $\begin{array}{ll}\text { - } & \text { type (equipment, employees) } \\
\text { - } & \text { skills } \\
\text { - } & \text { multi-project }\end{array}$ & $\begin{array}{l}\text { - } \text { type (renewable, non-renewable, cumu- } \\
\text { lative, required space etc.) } \\
\text { - } \text { resource usage and levelling } \\
\text { - } \text { resource availability, } \\
\text { - } \text { resource capacities, } \\
\text { - } \text { mullis } \\
\text { - } \text { modes }\end{array}$ \\
\hline risk & $\begin{array}{l}\text { - risk identification (internal/external } \\
\text { risks), } \\
\text { - risk assessment, } \\
\text { - risk mitigation=change manage- } \\
\text { ment }\end{array}$ & 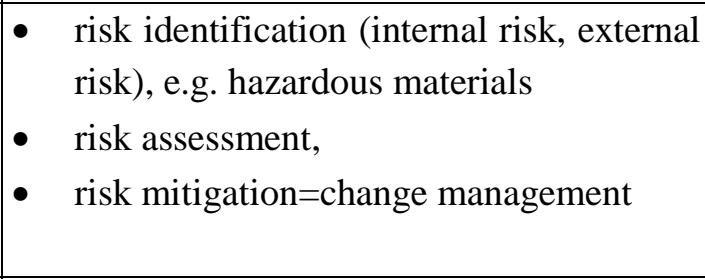 \\
\hline quality & $\begin{array}{ll}\text { - } & \text { environmental standards, } \\
\text { - } & \text { social standards, } \\
\text { - } & \text { product quality (material) }\end{array}$ & 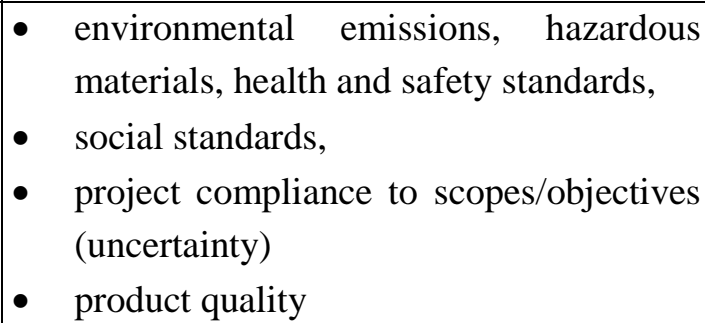 \\
\hline
\end{tabular}




\section{Review of project planning methods for deconstruction}

This section provides an overview of currently applied methods in strategic and operational deconstruction project planning literature. For each method, the identified requirements of Table 1 are matched. With the help of this classification, appropriate methods for the planning of future deconstruction projects and related gaps for future research are identified. The result is presented in tabular form, to give a comprehensive and concise overview.

As project planning methods highly differ due to their respective planning level, strategic and operational method approaches are distinguished for the analysis. Within this context, in section 3.1 an analysis of strategic planning methods, which are especially important for long range deconstruction projects, e.g. the deconstruction of nuclear power plants with about 10 to 20 years, is given. In this study, we mainly focus on operational planning of deconstruction projects. Consequently, respective deconstruction project planning methods are examined in more detail in section 3.2.

\subsection{Strategic planning methods}

Literature on strategic project planning, in terms of strategic decision support for the overall project due to the requirement fields time, cost, quality, resources and risks (see Table 1) is widespread. Some methods of strategic project planning are applied in deconstruction projects and will be analysed in the following. Except of Anumba et al. (2003), Kourmpanis et al. (2008b), Coelho and de Brito (2013), Liu et al. (2005) and Liu et al. (2003), the methods provide decision support for planning the overall deconstruction strategy regarding project compliance to scopes/objectives.

Kourmpanis et al. (2008b) and Liu et al. (2005) defined different combinations of deconstruction processes and deconstruction material management strategies and evaluated them qualitatively, but did not provide decision support in terms of a specific strategy. Anumba et al. (2003), Coelho and de Brito (2013) and Liu et al. (2003) quantitatively compared deconstruction strategies with the help of case 
studies. Anumba et al. (2003) assessed deconstruction strategies with respect to costs, durations, environmental and social standards and touched risks, for instance due to statics, as well as health and safety. Coelho and de Brito (2013) evaluated overall deconstruction project strategies based on costs, durations and global environmental impacts in the form of scenarios. Liu et al. (2003) focused on deconstruction project costs of different strategies.

Kourmpanis et al. (2008a) applied the multi-criteria decision analysis method PROMETHEE II to provide decision support regarding a specific combination of one overall deconstruction project strategy and one overall deconstruction material management option, due to different strategic and qualitative economic, environmental, technical and social criteria.

Besides Kourmpanis et al. (2008a), also Abdullah (2003), Abdullah et al. (2003), Abdullah and Anumba (2002), Anumba et al. (2008) and Anumba et al. (2003) included strategic economic, environmental, technical and social criteria for decision making. The utilized economic decision-criteria were for instance, overall project cost and time scope. Environmental aspects encompassed for instance, raw material and hazardous material management and impacts on the local environment in planning on the overall (de-)construction project. The material quality in the form of reuse and recycling rates was evaluated as well. Technical aspects, such as structural characteristics, including building heights, construction types, technique suitability and stability, were also considered to provide decision support. Furthermore, qualitative criteria of social aspects, such as skills, were included in strategic decision making. Abdullah (2003), Abdullah et al. (2003), Abdullah and Anumba (2002) and Anumba et al. (2008) used a two-step method for strategic planning. Firstly, an Analytic Hierarchy Process (AHP) was applied to select adequate deconstruction strategies, due to the different qualitative economic, environmental, technical and social decision criteria. Secondly, these selected adequate strategies were quantitatively assessed in terms of cost. The result was a ranking of overall deconstruction project strategies according to the lowest costs of the overall project, including single project activities. Further social criteria in these studies were health and safety of workers on site, priorities of legislations and public acceptance. Skills encompassed existing experiences of workers and might also be counted to the social criteria, as well as to the economic criteria regarding resource productivity 
(Abdullah, 2003; Abdullah et al., 2003, Abdullah and Anumba, 2002; Anumba et al., 2008; Anumba et al., 2003). Furthermore, internal and external risks were considered as sub-criteria of danger to workers and to the public, as well as in terms of the structure stability (Abdullah, 2003; Abdullah et al., 2003; Anumba et al., 2003).

Table 2 gives an overview of the strategic planning approaches in deconstruction, as described above. 
Table 2: Review of strategic project planning methods for deconstruction projects

\begin{tabular}{|c|c|c|c|c|c|c|c|c|c|c|}
\hline $\begin{array}{l}\text { Fields of } \\
\text { consid- } \\
\text { eration }\end{array}$ & $\begin{array}{l}\text { Requirements to consider for stra- } \\
\text { tegic deconstruction planning }\end{array}$ & 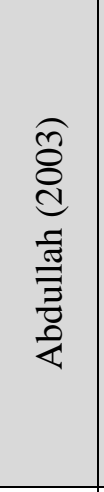 & 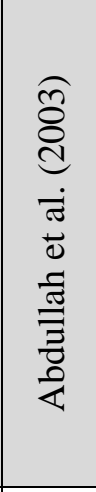 & 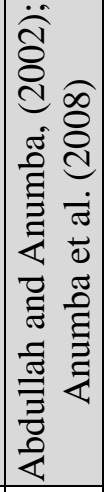 & 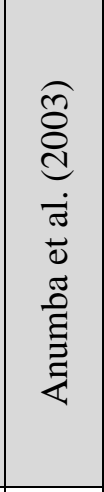 & 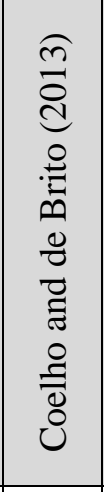 & 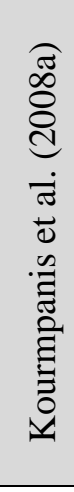 & 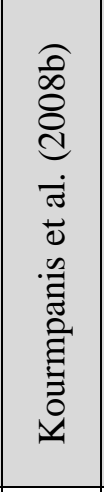 & 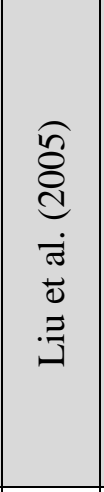 & 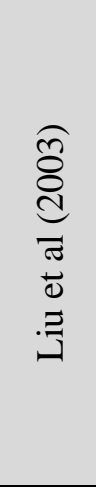 \\
\hline time & - $\quad$ overall project duration & $\mathrm{X}$ & $X$ & $\mathrm{X}$ & $\mathrm{X}$ & $\mathrm{X}$ & - & $\mathrm{X}$ & $\mathrm{X}$ & $\mathrm{X}$ \\
\hline $\cos t$ & $\begin{array}{l}\text { - overall project costs in general } \\
\text { overall direct costs of process- } \\
\text { es of deconstruction and mate- } \\
\text { rial handling } \\
\text { - indirect costs of the site in } \\
\text { terms of site facilities }\end{array}$ & $\begin{array}{l}- \\
X\end{array}$ & $\begin{array}{l}- \\
X\end{array}$ & $\begin{array}{l}- \\
X\end{array}$ & $\begin{array}{c}X \\
-\end{array}$ & $\begin{array}{c}X \\
-\end{array}$ & $\begin{array}{l}X \\
X\end{array}$ & $\begin{array}{l}X \\
X\end{array}$ & $\begin{array}{l}X \\
-\end{array}$ & $\begin{array}{l}X \\
-\end{array}$ \\
\hline $\begin{array}{l}\text { re- } \\
\text { sources }\end{array}$ & $\begin{array}{ll}\text { - } & \text { type (equipment, employees) } \\
\text { - } & \text { skills } \\
\text { - } & \text { multi-project }\end{array}$ & $\begin{array}{l}X \\
X \\
-\end{array}$ & $\begin{array}{l}X \\
X \\
-\end{array}$ & $\begin{array}{l}X \\
X \\
-\end{array}$ & $\begin{array}{l}- \\
- \\
-\end{array}$ & $\begin{array}{l}X \\
X \\
-\end{array}$ & $\begin{array}{l}X \\
X \\
-\end{array}$ & $\begin{array}{l}- \\
- \\
-\end{array}$ & $\begin{array}{l}- \\
- \\
-\end{array}$ & $\begin{array}{l}X \\
- \\
-\end{array}$ \\
\hline risk & 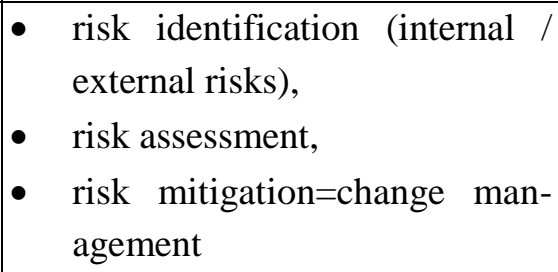 & - & - & - & - & - & $(\mathrm{X})$ & - & - & $\begin{array}{l}- \\
- \\
-\end{array}$ \\
\hline quality & $\begin{array}{l}\text { - } \quad \text { environmental standards, } \\
\text { - } \quad \text { social standards, } \\
\text { - }\end{array}$ & $\begin{array}{l}X \\
X \\
X\end{array}$ & $\begin{array}{l}X \\
X \\
X\end{array}$ & $\begin{array}{l}X \\
X \\
X\end{array}$ & $\begin{array}{l}X \\
X \\
X\end{array}$ & $\begin{array}{l}X \\
- \\
-\end{array}$ & $\begin{array}{l}X \\
X \\
X\end{array}$ & $\begin{array}{l}- \\
- \\
X\end{array}$ & $\begin{array}{l}- \\
- \\
X\end{array}$ & $\begin{array}{l}- \\
-\end{array}$ \\
\hline & Methods used & 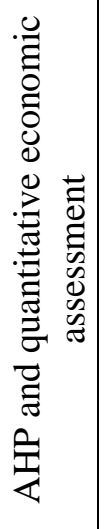 & 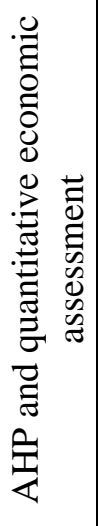 & 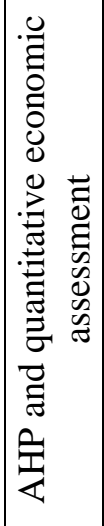 & 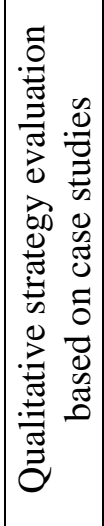 & 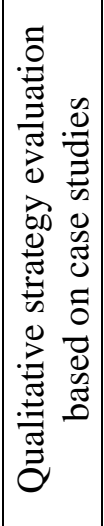 & 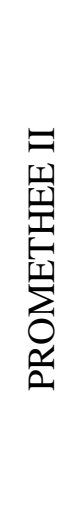 & 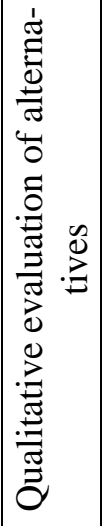 & 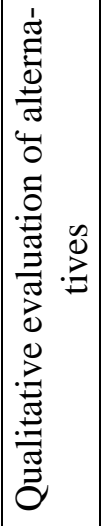 & 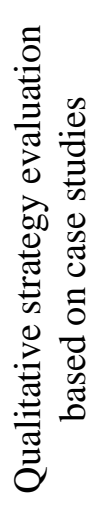 \\
\hline \multicolumn{11}{|c|}{$\begin{array}{l}\mathrm{X}: \text { model/method explicitly considers this aspect } \\
(\mathrm{X}) \text { : model/method mentions this aspect, but does not consider it in the model } \\
\text {-: not mentioned/considered }\end{array}$} \\
\hline
\end{tabular}


The above-mentioned methods of strategic deconstruction project planning do not consider planning of multiple deconstruction projects. Only Li et al. (2015) examined multi-project planning, by addressing strategic planning of deconstruction projects to some extent.

\subsection{Operational planning methods}

In operational methods, project planning is mostly performed based on single project activities (Schultmann, 1998; Schwindt and Zimmermann, 2015; Węglarz et al., 2011). General traditional operational project planning methods focus on the reduction of the project duration (Herroelen and Leus, 2005). Therefore, some methods consider activity precedence and resource constraints in terms of renewable and non-renewable resources. To reduce/minimise project duration or project cost on operational level, resource constrained project scheduling problems (RCPSP) are applied (Brucker et al., 1999; Hartmann and Briskorn, 2010). RCPSP exist for single and multi-projects (Herroelen and Leus, 2004; Kao et al., 2006), as well as with single and multi-modes (so called multi-mode resource constrained project scheduling problems (MRCPSP)) in the sense of alternative activity executions and mode assignments with different resource demands (Schultmann, 1998; Schwindt and Zimmermann, 2015; Węglarz et al., 2011).

Project planning methods can also be differentiated into project planning under certainty and project planning under risk or uncertainty. In addition, there are approaches aiming at a baseline schedule that is available before project start, while others provide the decision maker with a scheduling strategy or policy. Although literature on operational project planning is vast, project planning methods for the deconstruction of buildings and their description in literature are limited to a relatively small number. There are only a few research approaches to operational deconstruction project planning providing detailed planning of single deconstruction activities. E.g. robust RCPSP methods and their problem variants are numerous, but applied works in deconstruction are rare (Schultmann, 1998, 2003; Schultmann and Rentz, 2001, 2003; Sunke, 2009) and do not appropriately consider uncertainties. Most research approaches to operational deconstruction project planning include case study-based, quantitative, activity-related data of duration times, costs and resource usage (Schultmann and Sunke, 2007a, 
b; Schultmann and Rentz, 2001, 2003; Seemann, 2003; Schultmann, 1998, 2003). Bartels (2009) used an operational project planning approach. However, his time slices in the model (between 3 and 12 months) were so long, that it can be classified as a hybrid or meta approach between operational and strategic project planning.

Main approaches regarding deconstruction planning and scheduling optimisation stem from Schultmann, Rentz and Spengler. The approaches of Schultmann, Spengler, Rentz and Seemann offer operational decision support on simultaneous resource and capacity planning, to minimise deconstruction project makespan. However, these models have some constraints, such as no modelling of nonrenewable resources (e.g. limited project budget) (Schultmann, 1998) or uncertainties. This central optimisation-based work on deconstruction project planning includes a building auditing support and an optimisation tool for building deconstruction project planning in MS ACCESS 1998 (Schultmann, 1998, 2003; Schultmann et al., 1997; Schultmann and Rentz, 2001, 2003). The calculation in this early work was based on pre-measured building element dimensions and user assumptions regarding building element material and quality. With the help of their applied optimisation concepts, Schultmann and Rentz (Schultmann, 1998; Schultmann and Rentz, 2001) focused on the minimisation of makespan in deterministic/fixed precedence networks with deterministic parameters. Scheduling applications in deconstruction projects have been mainly limited to deterministic approaches, yet (Schultmann, 1998, 2003; Schultmann et al., 1997; Spengler, 1998; Sunke, 2009). These deterministic approaches were complemented by several additional extensions that are described in the following.

Schultmann and Sunke (2007a) extended the above described approach by additionally considering the recycling options of each building element and the related energy-saving effects due to different deconstruction activities. Furthermore, Schultmann and Sunke (2007b) developed an approach to solve multi-project scheduling problems, which allows decision makers to plan their resources in their project portfolio. With this approach, Schultmann and Sunke (2007b) connected the strategic and the operational viewpoint in deconstruction project planning. Schultmann and Sunke (2006) included the recovery rate of building elements and materials into project planning. This was done via reformulation of the objective function into maximisation of the recovery rate of all deconstruction activities in 
all modes and all materials. Sunke (2009) generally mentioned deconstruction optimisation models, but stayed unclear regarding their application in buildings or related uncertainties.

Spengler $(1993,1998)$ formulated a mathematical optimisation as a mixed-integer linear problem (MILP) for the deconstruction of complex products and components in general, but restricted to the consideration of deconstruction and recycling cost and maximisation of the marginal return. The described example of Spengler identified the optimum degree of deconstruction with the maximal marginal return. Nevertheless, it was restricted to a single-mode, cost minimisation problem for the deconstruction of a microwave oven, which is far less complex than the deconstruction of buildings. Spengler $(1993,1998)$ calculated the annual amount of used products that can be expected by a recycling enterprise and the resulting recycling cost which constitutes the objective value. Uncertainties were addressed and formulated in a fuzzy linear program (FLP) that results from long lifecycles, the available recycling techniques and capacities. Further works of Spengler in this area included approaches to the determination of the optimal deconstruction depth and the modelling of deconstruction processes via petri nets (Spengler, 1998).

Another mixed-integer linear problem (MILP) for operational building deconstruction planning was applied by Aidonis et al. (2008). The method includes decision making on single deconstruction project stages in terms of the two alternatives "demolition" and "selective deconstruction" with respective activities and precedence. The objective function maximises the profit from selling deconstruction waste minus fixed and variable costs of deconstruction. In each stage, decisions are made on the selective deconstruction of the next stage or the demolition of the total rest of the building. Hence, there is one mode related to the single project stages and one mode related to the deconstruction of the whole building (rest).

Bartels (2009) formulated the multi-skill bi-modal RCPSP with minimisation of discounted cash flows under time constraints ( $\min / \max$ time lags) and with renewable and cumulative resources with variable resource demand for deconstruction of nuclear power plants and resulting debris stocks. The MRCPSP for nuclear power plant deconstruction was formulated as a long-term project planning 
problem with very aggregated planning in 3 months time slices, that was accompanied by a mediumterm (3 years) and short-term (0.5 years) planning (Bartels, 2009). In his approach, Bartels restricted to the aggregated project plan and did not consider influences on the sub-plans.

Project management methods for nuclear power plant deconstruction were presented by Yanagihara et al. (2001) and Iguchi et al. (2004). Yanagihara et al. (2001) described a database model (COSMARD) that includes creation of a work breakdown structure, PERT scheduling with precedence constraints and cost estimation functionalities based on experience values. Estimation values of resource needs, radioactivity doses, duration and costs were derived per building element/facility component and based on an experience database. Both authors mentioned radioactivity dose and exposure scheduling, which can be classified as the consideration of environmental and social standards in deconstruction project planning.

Simulation methods in deconstruction planning were considered in works of Akbarnezhad et al. (2012, 2014), Cheng and Ma (2012) and Seemann (2003). Recent trends show the application shift from building information models (BIM) initially used in design processes to BIM application in retrofitting (and even deconstruction) projects. Here, depicted operational mass flow models of Akbarnezhad et al. (2012, 2014) and Cheng and Ma (2012) are based on information from BIM and consider the deconstruction of single buildings. Akbarnezhad et al. $(2012,2014)$ proposed a framework for evaluating and comparing the effects of various alternative deconstruction strategies on cost, energy use and carbon footprint of deconstruction projects. They examined a scenario-based (not activity-based) sensitivity analysis of deterministic net present costs for deconstruction, shipping, reprocessing and disposal (landfilling), as well as of energy and carbon embodiments of a building or structure that was previously represented in BIM (Akbarnezhad et al., 2014). To identify the most sustainable deconstruction strategy, available building information, the travelling distances to recycling and disposal facilities, deconstruction and recycling or disposal costs, energy and emission embodiments were used. Nevertheless, uncertainty in the model parameters was not considered by Akbarnezhad et al. (2014). However, these works focused on the quantity take-off, mass and cost calculation, aiming at ordering the exact number of hauling trucks, calculating the demand of hauling truck frequency (Cheng and Ma, 
2012) and calculating the masses from renovation and deconstruction measures designated for recycling or disposal facilities. Seemann (2003) described simulations of sorting, processing and recycling techniques as an extension to the works of Schultmann (1998).

Table 3 provides an overview of the previously described operational planning methods in deconstruction.

Table 3: Review of operational project planning methods for deconstruction projects

\begin{tabular}{|c|c|c|c|c|c|c|c|c|c|c|c|c|c|c|c|}
\hline $\begin{array}{l}\text { Fields of } \\
\text { considera- } \\
\text { tion }\end{array}$ & $\begin{array}{l}\text { Requirements to consid- } \\
\text { er for operational decon- } \\
\text { struction planning }\end{array}$ & 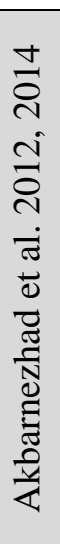 & 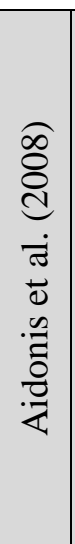 & 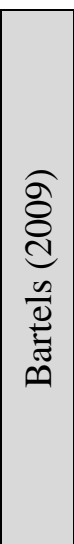 & 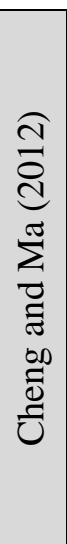 & 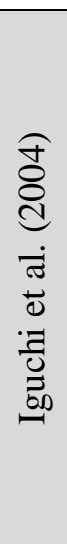 & 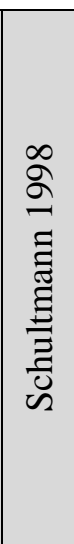 & 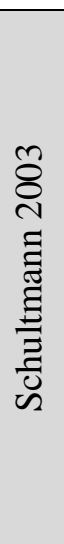 & 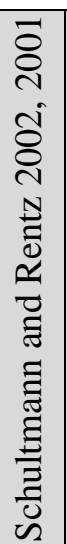 & 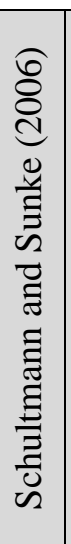 & 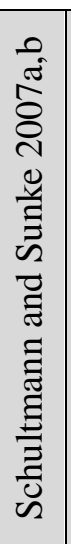 & 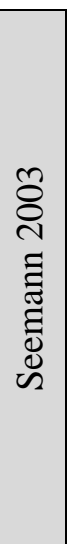 & 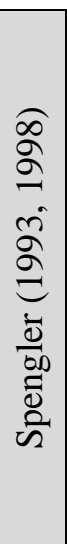 & 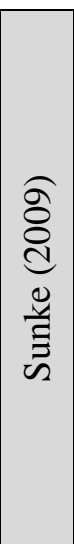 & 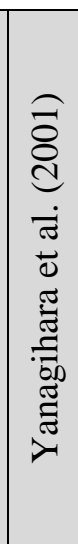 \\
\hline time & $\begin{array}{l}\text { - activity durations, } \\
\text { time restrictions } \\
\text { (e.g. deadlines, idle } \\
\text { times, setup time, } \\
\text { due dates, release } \\
\text { dates), } \\
\text { - precedence, } \\
\text { - time lags, etc. }\end{array}$ & - & $\begin{array}{l}- \\
-\end{array}$ & $\begin{array}{l}X \\
X\end{array}$ & $\begin{array}{l} \\
-\end{array}$ & $\begin{array}{l}X \\
\end{array}$ & $\begin{array}{l}X \\
-\end{array}$ & $\begin{array}{l}\mathrm{U} \\
-\end{array}$ & X & $\begin{array}{l}X \\
X\end{array}$ & $\begin{array}{l}X \\
-\end{array}$ & $\begin{array}{l}X \\
-\end{array}$ & $\begin{array}{l}X \\
-\end{array}$ & $\begin{array}{l}X \\
-\end{array}$ & $\begin{array}{l}\mathrm{U} \\
-\end{array}$ \\
\hline $\cos t$ & 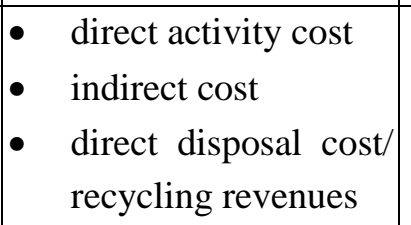 & $\begin{array}{l}X \\
X \\
X\end{array}$ & $\begin{array}{l}X \\
X \\
X\end{array}$ & $\begin{array}{c}X \\
X^{*} \\
-\end{array}$ & $\begin{array}{l}- \\
- \\
X\end{array}$ & $\begin{array}{l}X \\
- \\
-\end{array}$ & $\begin{array}{c}X \\
- \\
X\end{array}$ & $\begin{array}{c}X \\
- \\
X\end{array}$ & $\begin{array}{c}X \\
- \\
X\end{array}$ & $\begin{array}{c}X \\
- \\
X\end{array}$ & $\begin{array}{c}X \\
- \\
X\end{array}$ & $\begin{array}{c}X \\
- \\
X\end{array}$ & $\begin{array}{c}\mathrm{U} \\
- \\
\mathrm{U}\end{array}$ & $\begin{array}{c}X \\
- \\
X\end{array}$ & $\begin{array}{c}X \\
- \\
X\end{array}$ \\
\hline resources & 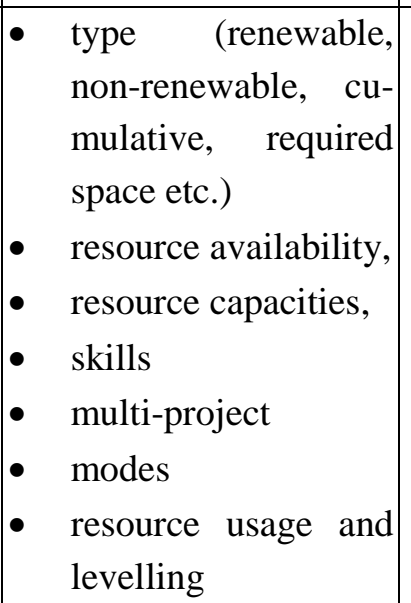 & - & $\begin{array}{l}- \\
- \\
- \\
- \\
- \\
-\end{array}$ & $\begin{array}{l}X \\
X \\
X \\
- \\
X \\
-\end{array}$ & $\begin{array}{l}- \\
X \\
- \\
- \\
- \\
-\end{array}$ & $\begin{array}{l}X \\
X \\
- \\
- \\
- \\
-\end{array}$ & $\begin{array}{c}X \\
X \\
- \\
- \\
X \\
(X)\end{array}$ & $\begin{array}{l}X \\
X \\
- \\
- \\
X \\
-\end{array}$ & $\begin{array}{l}X \\
X \\
- \\
- \\
X \\
-\end{array}$ & $\begin{array}{c}X \\
X \\
- \\
- \\
X \\
-\end{array}$ & $\begin{array}{c}X \\
X- \\
- \\
- \\
X \\
-\end{array}$ & $\begin{array}{l}- \\
X \\
- \\
- \\
X \\
-\end{array}$ & $\begin{array}{c}- \\
\mathrm{U} \\
- \\
- \\
- \\
-\end{array}$ & $\begin{array}{c}X \\
X \\
- \\
- \\
X \\
(X)\end{array}$ & $\begin{array}{l}- \\
- \\
- \\
- \\
- \\
-\end{array}$ \\
\hline
\end{tabular}




\begin{tabular}{|c|c|c|c|c|c|c|c|c|c|c|c|c|c|c|c|}
\hline $\begin{array}{l}\text { risk / uncer- } \\
\text { tainty }\end{array}$ & $\begin{array}{|ll|}\text { - } & \text { risk identification } \\
& \text { (internal / external } \\
& \text { risks), } \\
\text { - } & \text { risk assessment, } \\
\text { - } & \text { risk mitiga- } \\
& \text { tion=change man- } \\
& \text { agement }\end{array}$ & $\begin{array}{l}- \\
-\end{array}$ & $\begin{array}{l}- \\
-\end{array}$ & - & $\begin{array}{l}- \\
-\end{array}$ & - & - & - & - & - & - & - & $\begin{array}{c}X \\
-\end{array}$ & - & $\begin{array}{l}- \\
-\end{array}$ \\
\hline \multirow[t]{2}{*}{ quality } & 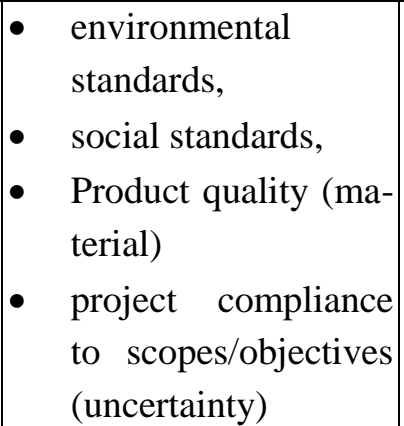 & \begin{tabular}{|c|}
$\mathrm{X})$ \\
- \\
$\mathrm{X}$ \\
- \\
-
\end{tabular} & $\begin{array}{l}- \\
- \\
- \\
X\end{array}$ & - & $(\mathrm{X})$ & $\begin{array}{c}\mathrm{X} \\
(\mathrm{X}) \\
- \\
-\end{array}$ & $\begin{array}{c}- \\
- \\
X \\
(X)\end{array}$ & $\begin{array}{l}- \\
X\end{array}$ & $\begin{array}{l}- \\
X\end{array}$ & - & $\begin{array}{l}- \\
X\end{array}$ & $\begin{array}{l}- \\
- \\
-\end{array}$ & $\begin{array}{l}- \\
X\end{array}$ & - & $\begin{array}{c}\mathrm{X} \\
(\mathrm{X}) \\
-\end{array}$ \\
\hline & Methods used & 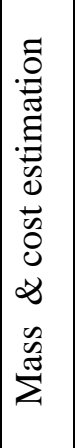 & 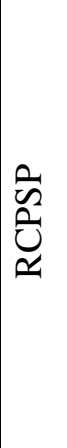 & $\begin{array}{l}\hat{\tilde{~}} \\
\text { 己े } \\
\approx\end{array}$ & 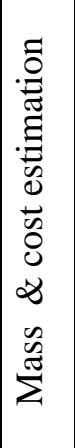 & 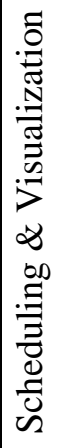 & 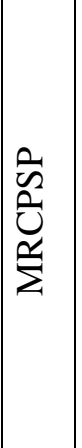 & 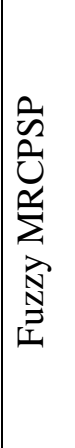 & \begin{tabular}{l}
$\hat{\tilde{n}}$ \\
$\hat{\nu}$ \\
\multirow{2}{z}{}
\end{tabular} & 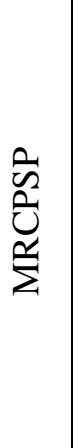 & 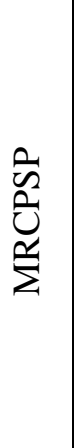 & 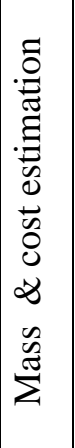 & $\begin{array}{l}\hat{\tilde{\nu}} \\
\text { 己े } \\
\approx\end{array}$ & $\begin{array}{l}\hat{\tilde{n}} \\
\hat{\nu} \\
\stackrel{\alpha}{\Sigma}\end{array}$ & 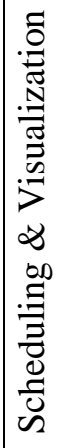 \\
\hline \multicolumn{16}{|c|}{ X: model/method explicitly considers this aspect } \\
\hline \multicolumn{16}{|c|}{ U: model/method considers this aspect together with uncertainty } \\
\hline \multicolumn{16}{|c|}{-: not mentioned/considered } \\
\hline \multicolumn{16}{|c|}{ *: storage cost } \\
\hline
\end{tabular}




\section{Discussion and Conclusion}

This paper provides a comprehensive overview of project planning literature and methods applicable for deconstruction planning of buildings. Since an infinite number of literature contributions concerning project planning in general is available, we focused our review on methods for deconstruction project planning. Furthermore, deconstruction planning differs from the planning of other projects, for instance regarding health and safety issues due to hazardous materials and impacts on the local environment and human beings. Nevertheless, the transferability of planning methods of for example construction project planning to deconstruction project planning could have been examined as well.

Altogether, we analysed different strategic and operational planning methods for deconstruction projects in this study. We first defined requirements that are important to consider in the planning of deconstruction projects. Subsequently, we provided a detailed review of literature and planning methods for deconstruction projects. We analysed and evaluated each method based on the requirements defined beforehand.

Since to the authors' knowledge, no literature with requirements to consider for the deconstruction planning is available, the requirements in this study were derived from the project management standard ISO 21500. In future research, a detailed examination of requirements for the deconstruction planning, e.g. with the help of expert interviews, could be carried out.

On the one hand, we found out that several planning methods meet the requirements of deconstruction projects, e.g. for deterministic time, cost and resource scheduling. The identified methods are listed in a table to support industry professionals and project managers to find appropriate planning methods for the planning of future deconstruction projects. On the other hand, we found out that several major issues are not yet considered by current planning methods for deconstruction projects. These research gaps should be the topic of future research.

A few of the qualitative and quantitative deconstruction planning methods allow detailed planning of and decision-making about the single process activities (Schultmann, 1998). However, current compu- 
tational limits reveal, that a certain number of activities and resources, and thus a specific level of detail, cannot be undercut due to a very high computational effort in exactly solving such project planning problems (e.g. in Schultmann (1998) with the number of activities and resources or in Bartels (2009) with the time slices/timely granularity). Therefore, new efficient methods for detailed project planning (especially scheduling) must be developed or adapted for the application case "deconstruction projects". Furthermore, the improvement of computer performance will enable the planning in more detail. In general, there are already some methods from operations research that can be applied for large projects. But so far, these methods have not been adapted for the planning of deconstruction projects.

Furthermore, we found out that current operational research methods focus on single-criteria or singleobjective project planning and time modelling. Multi-criteria project planning and decision making is mainly performed on strategic but not on operational level. Future research should focus on the integration of more than a single project objective, to increase realism in the project planning models. Additionally, besides the modelling of time, further objectives like economic criteria in terms of total deconstruction project cost minimisation, quality objectives in the form of customer satisfaction or product quality (e.g. the produced recycling material) in deconstruction project planning should be investigated.

In the context of project quality, the consideration of environmental criteria focuses on materialrelated issues in deconstruction project planning to date. In strategic planning methods, other environmental criteria, such as impacts on the local environment, are partly qualitatively assessed. In operational planning, there is only one research approach (Kühlen et al., 2014) which quantitatively considers local environmental impacts of single deconstruction activities. In this regard, the focus is on local environmental impacts of noise, dust and vibrations. Other local and global environmental impacts are not integrated in deconstruction planning at present. Moreover, the compliance to environmental standards is not given by current project planning methods. Additionally, no current sensors and techniques are conventionally available to measure existing impacts. 
As project quality can also address customer satisfaction, the inclusion of different stakeholders with their differing objectives, interests and information is important, but it has not yet been considered in current research of deconstruction project planning. Hence, further studies and methods, especially in operational planning on environmental criteria and stakeholder management in deconstruction projects, are necessary. This might be very promising and needed when it comes to the project planning of long-term deconstruction projects, such as the deconstruction of nuclear power plants.

Since several modifications and the state of repair and contamination of buildings and building elements are often not documented in the planning of deconstruction projects, uncertainties should be considered. We found out that current deconstruction planning approaches do not consider uncertainty and risk beyond the definition of a standard risk charge. Although some research approaches have considerable long planning horizons, where uncertainties prevail, such as Bartels (2009), Yanagihara et al. (2001) or Iguchi et al. (2004), these approaches do not yet include uncertainty or risk into their decision making. Thus, future research should focus on uncertainties and risk management in deconstruction planning.

Uncertainties could also be reduced with approaches of virtual prototyping or other sensor data to find out more building information for deconstruction planning. Therefore, current planning methods could be combined with digital building models, such as BIM, with approaches of virtual prototyping or with other sensor data. These newer technologies might also enhance the possibilities in decision support in project management and controlling phases of deconstruction projects. 


\section{References}

Abdullah, A. (2003), Intelligent selection of demolition techniques, $\mathrm{PhD}$ Thesis, Loughborough University.

Abdullah, A.; Anumba, C. J.; Durmisevic, E. (2003), "Decision Tools for Demolition Techniques Selection", in 11th Rinker International Conference on Deconstruction and Materials Reuse, Gainesville, Florida, USA, 7 - 10 May 2003, Chini, A. R., (Ed.), pp. 55-72.

Abdullah, A.; Anumba, C. J. (2002), "Decision Model for the Selection of Demolition Techniques”, in International Conference in Advanced Building Technology, Sheraton Hong Kong Hotel, HK, 4 6 December, Anson, M., Ko, J. M. and Lam, E. S. S., (Eds.), Vol. 2, pp. 1671-1679.

Aidonis, D.; Xanthopoulos, A.; Vlachos, D.; Iakovou, E. (2008), “On the optimal deconstruction and recovery processes of end-of-life buildings", in Proceedings of the 2nd International Conference on Waste Management, Water Pollution, Air Pollution, Indoor Climate (WWAI'08). 2008, pp. 211-216.

Akbarnezhad, A., Ong, K..; Chandra, L. (2014), "Economic and environmental assessment of deconstruction strategies using building information modelling", Automation in Construction, Vol. 37, pp. 131-144.

Akbarnezhad, A., Ong, K., Chandra, L.; Lin, Z. (2012), "Economic and Environmental Assessment of Deconstruction Strategies Using Building Information Modeling", in Proceedings of Construction Research Congress 2012: Construction Challenges in a Flat World, West Lafayette, USA, pp. $1730-1739$.

Anumba, C. J.; Abdullah, A.; Ruikar, K. (2008), “An Integrated System for Demolition Techniques Selection”, Architectural Engineering and Design Management, Vol. 4 No. 2, pp. 130-148.

Anumba, C.; Abdullah, A.; Fesseha, T. (2003), "Selection of demolition techniques: a case study of the Warren Farm Bridge”, Structural Survey, Vol. 21 No. 1, pp. 36-48. 
Bartels, J.-H. (2009), Anwendung von Methoden der ressourcenbeschränkten Projektplanung mit multiplen Ausführungsmodi in der betriebswirtschaftlichen Praxis, PhD Thesis, Produktion und Logistik, Gabler Edition Wissenschaft, Wiesbaden.

Bredillet, C.N. (2003), "Genesis and role of standards: theoretical foundations and socio-economical model for the construction and use of standards", International Journal of Project Management, Vol. 21 No. 6, pp. 463-470.

Brucker, P., Drexl, A., Möhring, R., Neumann, K..; Pesch, E. (1999), "Resource-constrained project scheduling: Notation, classification, models and methods", European Journal of Operational Research, Vol. 112, pp. 3-41.

Cheng, J.; Ma, L. (2012), “A BIM-based System for Demolition and Renovation Waste Quantification and Planning", in Proceedings of the 14th International Conference on computing in Civil and Building Engineering (ICCCBE 2012), Moscow.

Coelho, A.; de Brito, J. (2013), "Conventional demolition versus deconstruction techniques in managing construction and demolition waste (CDW)". In Pacheco-Torgal, F.; Tam, V. W. Y.; Labrincha, J. A.; Ding, Y. and de Brito J. (Ed.), Handbook of recycled concrete and demolition waste, Woodhead Publishing Limited, Cambridge, 2013, pp. 141-185.

Garel, G. (2013), "A history of project management models: From pre-models to the standard models", International Journal of Project Management, Vol. 31 No. 5,pp. 663-669.

Hartmann, S.; Briskorn, D. (2010), "A survey of variants and extensions of the resource-constrained project scheduling problem", European Journal of Operational Research, Vol. 207 No. 1, pp. 114.

Herroelen, W.; Leus, R. (2005), "Project scheduling under uncertainty: Survey and research potentials”, European Journal of Operational Research, Vol. 165 No. 2, pp. 289-306.

Herroelen, W.; Leus, R. (2004), "Robust and reactive project scheduling: a review and classification of procedures", International Journal of Production Research, Vol. 42 No. 8, pp. 1599-1620. 
Iguchi, Y., Kanehira, Y., Tachibana, M.; Johnsen, T. (2004), "Development of Decommissioning Engineering Support System (DEXUS) of the Fugen Nuclear Power Station”, Journal of Nuclear Science and Technology, Vol. 41 No. 3, pp. 367-375. Kao, H.-P.; Wang, B.; Dong, J.; Ku, K.-C. (2006), “An event-driven approach with makespan/cost tradeoff analysis for project portfolio scheduling", Computers in Industry, Vol. 57 No. 5, pp. 379-397.

Kourmpanis, B.; Papadopoulos, A.; Moustakas, K.; Kourmoussis, F.; Stylianou, M.; Loizidou, M. (2008a), "An integrated approach for the management of demolition waste in Cyprus", Waste Management \& Research, Vol. 26 No. 6, pp. 573-581.

Kourmpanis, B.; Papadopoulos, A.; Moustakas, K.; Stylianou, M.; Haralambous, K. J.; Loizidou, M. (2008b), "Preliminary study for the management of construction and demolition waste", Waste Management \& Research, Vol. 26 No. 3, pp. 267-275.

Kühlen, A.; Volk, R.; Stengel, J.; Schultmann, F. (2014), “Deconstruction Project Planning Considering Local Environmental Impacts", in Proceedings of the 5th International Conference on Engineering, Project, and Production Management (EPPM), Port Elizabeth, South Africa, 2628.11.2014, pp. 22-33.

Li, Y.; Lu, Y.; Kwak, Y. H.; Dong, S. (2015), "Developing a city-level multi-project management information system for Chinese urbanization", International Journal of Project Management, Vol. 33 No. 3, pp. 510-527.

Liu, C.; Pun, S.; Langston, C. (2005), “A preliminary study on building demolition engineering and management”, World Transactions on Engineering and Technology Education, Vol. 4 No. 2, pp. 201-207.

Liu, C.; Lyle, B.; Langston, C. (2003), "Estimating Demolition Costs for Single Residential Buildings", AJCEB, Vol. 3 No. 2, pp. 33

Ó Conchúir, D. (2012), Overview of the PMBOK® Guide, Springer, Berlin, Heidelberg. 
PMI - Project Management Institute (2013), A guide to the Project Management Body of Knowledge (PMBOK guide), 5th edition, Project Management Institute, Newtown Square.

Schultmann, F. (2003), "Dealing with uncertainties in (de-)construction management - the contribution of fuzzy scheduling", in CIB Report 287 "Deconstruction \& Materials Reuse" - Proceedings of the 11th Rinker International Conference on Deconstruction and Materials Reuse (ed. A. Chini), CIB-Report, University of Florida, Gainesville, Florida, USA, pp. 73-82.

Schultmann, F. (1998), Kreislaufführung von Baustoffen - Stoffflußbasiertes Projektmanagement für die operative Demontage- und Recyclingplanung von Gebäuden, $\mathrm{PhD}$ Thesis. Erich Schmidt Verlag (Reihe Baurecht und Bautechnik), Berlin.

Schultmann, F.; Rentz, O. (2003), "Fuzzy Scheduling for the Dismantling of Complex Products", in Operations Research Proceedings 2002, Selected Papers of the International Conference on Operations Research (SOR 2002), Klagenfurt, U. Leopold-Wildburger, F. Rendl, and G. Wäscher, eds., Springer Verlag, Berlin, Heidelberg, New York, pp. 302-307.

Schultmann, F.; Rentz, O. (2001), "Environment-oriented project scheduling for the dismantling of buildings", OR Spektrum, Vol. 23, pp. 51-78.

Schultmann, F.; Sindt, V.; Ruch, M.; Rentz, O. (1997), „Schadstofforientierte Erfassung und Demontage von Gebäuden“, Abfallwirtschaftsjournal, Vol. 3, pp. 38-42.

Schultmann, F.; Sunke, N. (2007a), "Energy-oriented deconstruction and recovery planning”, Building Research \& Information, Vol. 35 No. 6, pp. 602-615.

Schultmann, F.; Sunke, N. (2007b), "Sustainable Management of Construction Projects", in CIB2007313 , pp. 2428-2440.

Schultmann, F.; Sunke, N. (2006), “Closed-loop oriented project management in construction: An approach for sustainable construction management", in Proceedings of the Conference Rethinking Sustainable Construction 2006, Sarasota, USA. 
Schwindt, C.; Zimmermann, J. (Eds.). (2015), Handbook on Project Management and Scheduling Vol. 1. International Handbooks on Information Systems, Springer, Clausthal-Zellerfeld.

Seemann, A. (2003), Entwicklung integrierter Rückbau- und Recyclingkonzepte für Gebäude - ein Ansatz zur Kopplung von Demontage, Sortierung und Aufbereitung, Berichte aus der Betriebswirtschaft, Shaker Verlag, Aachen.

Spengler, T. (1998), Bestimmung optimaler Demontagetiefen mit Hilfe der Fuzzy Linearen Optimierung. Industrielles Stoffstrommanagement - Betriebswirtschaftliche Planung und Steuerung von Stoff- und Energieströmen in Produktionsunternehmen. zugl. Karlsruhe, Universität, Habilitationsschrift, 1998, technological economics, Erich Schmidt Verlag (ESV), Berlin.

Spengler, T. (1993), Planungsmodelle zur deckungsbeitragsmaximalen Demontage und Verwertung komplexer Verbundprodukte. PhD Thesis, Univ. Karlsruhe (TH).

Steven, M. (2008), BWL für Ingenieure, 3rd edition, Oldenbourg, München.

Sunke, N. (2009), Planning of Construction Projects: A Managerial Approach. Siegen, Siegen.

Węglarz, J.; Józefowska, J.; Mika, M.; Waligóra, G. (2011), "Project scheduling with finite or infinite number of activity processing modes - A survey", European Journal of Operational Research, Vol. 208 No. 3, pp. 177-205.

Xanthopoulos, A.; Aidonis, D.; Vlachos, D.; Iakovou, E. (2012), “A planning optimisation framework for construction and demolition waste management", International Journal of Industrial and Systems Engineering, Vol. 10 No. 3, p. 257.

Yanagihara, S., Sukegawa, T., and Shiraishi, K. (2001), "Development of Computer Systems for Planning and Management of Reactor Decommissioning", Journal of Nuclear Science and Technology, Vol. 38 No. 3, pp. 193-202.

Zimmermann, J. (2001), Ablauforientiertes Projektmanagement. Modelle, Verfahren und Anwendungen. Habilitation, University of Karlsruhe. 